NASA Technical Memorandum 107315

AIAA-97-0546

\title{
A Proof of Concept Experiment for Reducing Skin Friction By Using a Micro-Blowing Technique
}

Danny P. Hwang

Lewis Research Center

Cleveland, Ohio

Prepared for the

35th Aerospace Sciences Meeting and Exhibit

sponsored by the American Institute of Aeronautics and Astronautics

Reno, Nevada, January 6-9, 1997

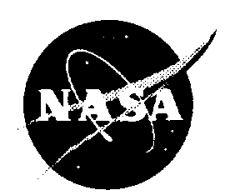

National Aeronautics and

Space Administration 


\title{
A PROOF OF CONCEPT EXPERIMENT FOR REDUCING SKIN FRICTION BY USING A MICRO-BLOWING TECHNIQUE*
}

\author{
Danny P. Hwang $\dagger$ \\ National Aeronautics and Space Administration \\ Lewis Research Center \\ Cleveland, Ohio 44135
}

\begin{abstract}
A proof of concept experiment for reducing skin friction has been conducted in the Advanced Nozzle and Engine Components Test Facility at the NASA Lewis Research Center. In this unique concept, called the micro-blowing technique (MBT), an extremely small amount of air was blown vertically through very small holes to reduce the surface roughness and to control the gradient of the flow velocity profile on the surface thereby reducing skin friction. Research revealed that the skin was the most important factor to make this concept achievable. The proposed skin consisted of two layers. The inner layer was a low permeable porous skin for distributing the blowing air evenly while the outer layer with small holes controlled the vertical or nearly vertical blowing air. Preliminary experimental results showed that the MBT has the potential of a very large reduction in skin friction below the skin friction of a nonporous plain flat plate. Of the skins tested, three have been identified as the MBT skins. They provided very low unblown skin friction such that a large skin friction reduction, below a flat plate value, was achieved with very small amounts of blowing air. The reduction in skin friction of 55 percent was achieved at the Mach number of 0.3 for the exhaust pressure of $0.85 \mathrm{~atm}$, and 60 percent reduction was obtained for the exhaust pressure of $0.24 \mathrm{~atm}$ (corresponding to $10700-\mathrm{m}$ altitude) at the same Mach number. A significant reduction in skin friction of over 25 percent was achieved for the exhaust pressure of $0.24 \mathrm{~atm}$ at the Mach number of 0.7 . This implied that the MBT could be applied to a wide range of flight conditions. It is also believed

that an additional 10 percent reduction could be obtained by eliminating the gap between the inner layer and the outer layer. The aspect ratio of the vertical small holes for the outer layer of the MBT skin should be larger than 4 based on the preliminary conclusion from this test. Many experiments are needed to find out the optimal MBT skin. The penalty associated with the MBT needs to be assessed. However, preliminary results indicated that the MBT could provide a 25 to 35 percent reduction for real-world application. The concept can be applied to not only an airplane, but also a missile, a submarine (micro-blow water instead of air), and an ocean liner.

\section{Symbols}

A area of test plate

AR aspect ratio, T/D

$\mathrm{C}_{\mathrm{f}}$ total skin friction coefficient, (skin friction force $) /\left(\frac{1}{2} \rho_{\infty} u_{\infty}^{2} A\right)$

$\mathrm{C}_{\mathrm{fo}}$ total skin friction coefficient of nonporous plain flat plate

D diameter of blowing holes, $\mathrm{mm}$

H shape factor (ratio of displacement thickness to momentum thickness)

$\mathrm{T}$ thickness of plate, $\mathrm{mm}$

u velocity component parallel to surface, $\mathrm{m} / \mathrm{sec}$

$\mathrm{u}_{\infty} \quad$ free stream velocity

y vertical distance from surface, $\mathrm{cm}$

$\rho_{\infty} \quad$ free stream density
\end{abstract}

*Patent pending.

tMember AIAA

This paper is declared a work of the U.S. Government and is not subject to copyright protection in the United States. 


\section{Introduction}

One of the most challenging areas of research in aerodynamics is the reduction of skin friction, especially for turbulent flow. Many techniques and methods have been tried as summarized in Refs. 1 and 2 . However, none of the techniques can provide significant reduction in skin friction for real-world application. For the past 20 years, attention has been focused on surface suction to delay transition so that a large area of the laminar flow region can provide skin friction reduction as summarized in Ref. 1. There are many problems associated with this technique. Laminar flow is very unstable and tries to transit into turbulent flow even with a very small foreign object present. Also, laminar flow is susceptible to flow separation. Therefore this technique still remains in the research stage. Another method is placing riblets on the surface; ${ }^{1}$ however, drag reduction is limited to under 8 percent.

One of the methods that has been ignored is the surface mass injection (or blowing) because many researchers believed that the penalty associated with blowing was very large because of the susceptibility of flow separation. Despite this shortcoming, many experiments were conducted in 1970's for a flat plate with no pressure gradient. 3-12 It was well established that blowing did significantly reduce skin friction with respect to the skin friction of the unblown porous plate. However the skin friction of unblown porous plates tested so far by many investigators was very high when compared with a nonporous flat plate value. ${ }^{13}$ It is impractical to reduce skin friction by blowing for these plates with high unblown skin friction because it requires a very large amount of blowing air (which blows away the boundary layer) to reduce the skin friction below a flat plate value.

The innovative skin friction reduction technique called the micro-blowing technique (MBT) (patent pending) has been tested in the Advanced Nozzle and Engine Components Test Facility 14 at the NASA Lewis Research Center, and the concept has been proven to achieve over 25 percent reduction in skin friction for a wide range of simulated flight conditions. Results of the tests are presented in this paper.

More assessment about the penalties associated with this new technique is required, but the preliminary results show that it is a very promising new technology for reducing skin friction of both laminar and turbulent flow.

\section{The Micro-Blowing Technique (MBT}

In this unique concept, an extremely small amount of air is blown vertically at the surface through very small holes with high aspect ratio (AR). This reduces the surface roughness and the gradient of the flow velocity profile on the surface thereby reducing skin friction.

\section{The MBT Skin}

The most important factor to make the MBT achievable is the skin. One of the proposed MBT skins consists of two layers as depicted in Fig. 1.

The inner layer is a low permeable porous skin for distributing the blowing air evenly while the outer layer with high AR holes controls the vertical or nearly vertical blowing air. In order to reduce the skin friction below a flat plate value, the skin friction of the unblown porous plate needs to be only slightly higher than the skin friction of a flat plate. The skin with less than 10 percent above the skin friction of a flat plate can be considered as a MBT skin.

Wilkinson 13 has tested several permeable surfaces, closest to our MBT skins in size and porosity of holes, and found that the unblown skin friction of these plates (which have holes with AR $<1$ ) was very high especially for high free stream flow. These plates cannot be considered as the MBT skins.

\section{Skins Tested}

A 30-micron high density polyethylene plate with a thickness of $9.14 \mathrm{~mm}$ was used for the inner layer throughout the test.

The gap between the inner layer and the outer layer was about $0.8 \mathrm{~mm}$. It was found later from Ref. 13 that elimination of the gap between two plates could provide an additional 10 percent reduction in skin friction.

Seven outer layers (each 12.36 by $25.06 \mathrm{~cm}$ ) have been tested, and the specifications of the plates are listed in Table I.

NASA PN2 and PN3 skins were laser drilled; the shape of the hole was irregular as shown in Fig. 2. The flow direction over the plate is also indicated in Fig. 2. It is believed that a streamline on the surface should pass over the holes as often as possible in order to get the benefit of vertical blowing air. 
GAC series plates were provided by Northrop Grumman Corporation; they were designed for acoustic testing. The smaller openings of the conical cross section were placed in touch with free-stream flow in the same way as that used for an acoustic liner.

\section{Test Facility}

The Advanced Nozzle and Engine Components Test Facility (CE22) 14 was modified for this experiment. A constant rectangular cross section duct (20.32 cm wide, $14.2 \mathrm{~cm}$ high, and $63.5 \mathrm{~cm}$ long) replaced the usual test article (designed for testing a nozzle). A 12.7-cm-long transition duct was used to connect the test section to the facility.

The facility provided stable Mach numbers from 0.3 to 0.7 . The exhaust pressure at the exit of the test section could be adjusted from 1.0 atm to near vacuum, and the supply total pressure could be as high as $2.7 \mathrm{~atm}$. A Mach number of 0.7 is very close to the cruise Mach number of most of the commercial airplanes, and any skin friction reduction at that speed which uses the MBT has application to a real aircraft.

\section{Apparatus and Instrumentation}

Figure 3 shows the balance used to measure skin friction. It was loaned by the Naval Surface Weapons Center, and the detailed description of the balance is in Ref. 4. The Linear Variable Differential Transformer (LVDT) was replaced by a load cell with a maximum loading of 500 grams. The accuracy of the load cell was \pm 0.25 percent. The balance was placed under the test section inside a sealed compartment, as shown in Fig. 4, to minimize air leakage through the gap $(0.2 \mathrm{~mm})$ between the plate and the tunnel floor. The top tunnel section was removed in Fig. 4. The test skins were placed $25.4 \mathrm{~cm}$ downstream from the transition duct in the constant pressure region. At the Mach number of 0.7 , the flow was slightly accelerated as a result of the boundary layer blockage. Because this was a proof of concept experiment, no attempt was made to correct the blockage by enlarging the cross section. There were two total pressure rakes. The total pressure rakes were built with tubing which had an outside diameter of $0.508 \mathrm{~mm}$. A total pressure rake (not shown) was located $0.635 \mathrm{~cm}$ from the side of the test plate, and the tips of the rake were placed at the location of the leading edge of the test plate. This total pressure rake was planned to be used as a total pressure rake at the leading edge of the test plate. The thickness of the boundary layer from the sidewall unexpectedly increased, and the rake was embedded in the sidewall boundary layer. Therefore, the measurements of this rake were not usable. Another total pressure rake, as shown in Fig. 4, was placed at the centerline on the tunnel floor; the openings of the tubes were $1.27 \mathrm{~cm}$ upstream of the trailing edge of the plate, and there was a very small vertical gap (less than $0.2 \mathrm{~mm}$ ) between the test plate and the nearest tube. This total pressure rake was used to calculate the momentum thickness and the velocities inside the boundary layer. A total pressure probe, a static pressure probe, and a total temperature thermocouple were placed at the entrance of the plate on the top surface of the tunnel (not shown) for the free stream Mach number measurement.

A 300-standard-liter/min (SLM) electronic mass flowmeter, as shown in Fig. 4, was used to measure the flow rate of blowing air.

\section{Calibration}

Another identical load cell was used to calibrate the load cell inside the balance. The calibration showed that the friction of the balance was very small because of the frictionless flexural pivots. The data were adjusted for this small difference during the data acquisition process.

The error introduced on the flexible bellows, as shown in Fig. 3, during 100 percent blowing was very small; it was not corrected during the test.

\section{Test Matrix}

The test plates were tested for 5 Mach numbers (i.e., $0.3,0.4,0.5,0.6$ and 0.7 ). The exhaust pressures used were $0.85 \mathrm{~atm}$ (Reynolds number $/ \mathrm{m}=5.36(10)^{5}$ to $9.24(10)^{5}$ ) and 0.24 atm (Reynolds number $/ \mathrm{m}=$ $1.49(10)^{5}$ to $3.81(10)^{5}$ ). The tests for $0.85 \mathrm{~atm}$ were terminated at the Mach number of 0.5 because the skin friction was much higher than the flat plate value. The micro-blowing flow rates for the test plates are indicated in Table II.

\section{$\underline{\text { Results and Discussion }}$}

The test results from the exhaust pressure of $0.24 \mathrm{~atm}$ are presented first.

A plain stainless steel flat plate without vertical holes was first tested. The good repeatability of the facility is shown in Fig. 5 for the results taken on August 4, 1995 and August 10, 1995. The total skin friction coefficients obtained from this test for a plain stainless steel flat plate were compared with the empirical formula of Ludwieg and Tillman based on 
the experimental results of Rotta 15 and are shown in Fig. 6. The skin friction coefficients from the tests being reported were the average value based on a 12.36 - by $25.06-\mathrm{cm}$ plate, and the momentum thickness was based on the downstream total pressure rake which gave higher momentum thickness than that at the center of the plate. However, the results were reasonably close.

The total skin friction coefficients of NASA PN2 at the Mach number of 0.7 for different blowing rates were calculated based on the momentum integral equation by using the downstream total pressure rake. Since the measurements of the upstream total pressure rakes were unusable, only the effect of blowing on the total skin friction coefficient was calculated. The results were compared with the direct measurement by using the balance shown in Table III.

As mentioned earlier, the calculated $C_{f}$ was based on the downstream boundary layer rake (not at the center of the plate), and $C_{f}$ was assumed to be a constant on the flat plate. However, the comparison between the measured $C_{f}$ and the calculated $C_{f}$ was excellent.

The momentum thickness of this plate without blowing was about 1 to $2 \mathrm{~mm}$.

The total skin friction coefficient of a nonporous flat plate $\left(\mathrm{C}_{\mathrm{fo}}\right)$ was measured and was considered as a reference skin friction coefficient. The skin friction ratios $\left(\mathrm{C}_{\mathrm{f}} / \mathrm{C}_{\mathrm{fO}}\right)$ were measured at different Mach numbers for different porous test plates. The skin friction ratios for unblown cases were shown in Fig. 7 for high altitude exhaust pressure. Only three porous plates (i.e., NASA PN2, NASA PN3, and GAC 1897) had unblown skin friction ratios lower than 1.1 (i.e., only 10 percent more than a flat plate) at the Mach number of 0.7 . These plates were considered as the MBT skins. The unblown skin friction ratios were so high for other skins that the reduction in skin friction below a flat plate value was not possible for practical application. Notice that the AR's of the MBT skins were 4 or higher. These small high AR holes were able not only to control the vertical blowing air during the micro-blowing but also to provide the low skin friction without blowing. The study of an open cavity flow with an AR of 5 using the Navier-Stokes code indicates that there are three vortices existing inside the cavity. Further study is needed to verify experimentally whether there exist three recirculating vortices inside the small high $A R$ holes without blowing. Since both ends of the hole are open, a slight difference in pressure could push the vortices out of the hole. Understanding these micro-physical phenomena is a challenge for aeronautical scientists. It is believed that the slip flow occurring on the surface of the MBT skin plays an important role in reducing the unblown skin friction. The porosity (percent open area) of the NASA plates was 23 percent. GAC 1897 had 50 percent porosity based on the large open circle. The porosity is 4 percent based on the small neck area of the hourglass-shaped cross section. Whether these large open areas contribute to the reduction in unblown skin friction needs to be investigated.

The skin friction ratios of three MBT skins are shown in Figs. 8 to 10 for the exhaust pressure of $0.24 \mathrm{~atm}$.

Figure 8 shows the skin friction ratio of NASA PN2. The unblown skin friction ratio at the Mach number of 0.3 is 5 percent lower than a flat plate value and increases to 10 percent more than a flat plate value at the Mach number of 0.7 . The low skin friction at the Mach number of 0.3 could be due to the lower effective roughness at lower Reynolds number and the 23 percent open area without skin. The general trend, as expected, is the reduction in skin friction when the blowing rate increases. The reduction is less at higher Mach numbers with the same blowing flow rate. About 60 percent reduction below a flat plate was achieved at the Mach number of 0.3 with 100 percent blowing rate $\left(0.205 \mathrm{~kg} / \mathrm{m}^{2} / \mathrm{sec}\right)$, while 28 percent reduction was obtained at the Mach number of 0.7 with the same blowing rate. The first 50 percent (i.e., below $0.1025 \mathrm{~kg} / \mathrm{m}^{2} / \mathrm{sec}$ ) of blowing did reduce 75 percent of the total reduction at the Mach number of 0.3 and 60 percent of the total reduction at the Mach number of 0.7. This indicates that, at the lower blowing rate, the MBT is more efficient for reducing turbulent skin friction. The micro-blowing air is believed to reduce the pressure difference inside the small holes with high AR resulting in reduction in skin friction. The NASA PN2 plate has circular cylindrical holes which are perpendicular to the surface. It is believed that this type of hole can more efficiently remove the pressure difference inside the hole than the hourglass-shaped hole (GAC 1897 plate). The microblowing air is also believed to lift the external streamlines up so that the external streamlines can flow more smoothly over the surface which is covered with a thin layer of air. Thus the MBT can reduce the roughness of the surface. This thin layer of air is also believed to cause slip flow on the surface. The blowing air also reduces the gradient of the velocity profile on the surface resulting in the reduction of the viscous shear friction. Again, the straight hole can lift the streamline better than the hourglass-shaped hole. Consequently, the NASA PN2 plate is more efficient than the GAC 1897 plate.

The results of NASA PN3 (Fig. 9) were identical 
to those of NASA PN2 up to the Mach number of 0.6 . Somehow the skin friction ratio of this plate increased slightly at the highest blowing rate. It could be the adverse effect of a manufacturing defect groove across the plate near the trailing edge of the plate.

The results of GAC 1897 (Fig. 10) were different from those of the NASA plates. The unblown skin friction ratio of GAC 1897 was 23 percent higher than a flat plate value at the Mach number of 0.3 , therefore the reduction of only 50 percent below a flat plate value was achieved at this Mach number with 100 percent blowing rate. However this plate had a very low unblown skin friction ratio at the Mach number of 0.7 (i.e., only 3 percent above a flat plate value), and 24 percent reduction in skin friction was obtained. As mentioned earlier, this plate was not as efficient as the NASA PN2.

Preliminary results showed that small holes with the AR of more than 4 can provide such a low unblown skin friction ratio that significant skin friction reduction below that of a flat plate can be achieved.

At very low blowing rates, the boundary layer growth was reduced because of the reduction in skin friction, while the boundary layer thickness increased slightly as a result of the addition of blowing air. The combined effect is shown in Fig. 11. It shows that the growth of the boundary layer thickness near the end of the plate with micro-blowing is very small. This could indicate that there was more room for reduction if a larger flow meter were available during the test.

Figure 12 is the skin friction ratio of NASA PN2 at the exhaust pressure of 0.85 atm. The unblown skin friction ratios were much higher than the cases with the exhaust pressure of 0.24 atm. The reduction of 55 percent below a flat plate value was achieved at the Mach number of 0.3. At the Mach number of 0.5 , the unblown skin friction ratio was so high that the skin friction was unable to be reduced below a flat plate value.

Figure 13 shows the effect of Reynolds number (based on the plate length of $25.06 \mathrm{~cm}$ ) on skin friction reduction for two pressure levels and two blowing rates. It is very clear that the reduction in skin friction diminishes with the same blowing rate when the Reynolds number increases.

The velocity profiles from the downstream rake of the test of two skins, GAC 1897 and GAC 2005, are shown in Fig. 14. GAC 2005 had an unblown skin friction twice as high as that of GAC 1897 based on the measurement by the balance as shown in Fig. 7 .
However, if the velocity profiles were extrapolated to zero on the surface, the gradient of the velocity profile on the surface of GAC 2005 is lower than that of GAC 1897 which implies lower viscous shear friction for GAC 2005. This contradiction leads to the belief that the boundary condition on the surface and the laminar sublayer just above the surface are more complicated than many scientists have believed. In order to improve the accuracy of computational fluid dynamics (CFD) analysis for predicting skin friction, a sophisticated turbulence model is needed to extend the accuracy to the surface and a more realistic boundary condition is required.

There was a gap of $0.8 \mathrm{~mm}$ between the inner layer and the outer layer for this test. An additional 10 percent reduction in skin friction might be possible by eliminating the gap based on the paper by Wilkinson. 13 However, it might be possible to eliminate the inner layer completely for a real application to minimize the pressure loss across the inner layer.

\section{Potential Application}

The high external flow on the surface of an airfoil or a nacelle provides a low pressure region on the surface. The suction boundary layer control usually requires large suction power against this low pressure, while the MBT can utilize this surface suction force to provide part of blowing air. For the same skin friction reduction, the higher blowing flow rate is needed for the higher external flow velocity. Therefore, the surface can adjust itself giving more suction force on the surface where the higher blowing rate is needed. Consequently, the penalty for supplying very low blowing air is believed to be very small.

Some of the blowing air could be bled off downstream to prevent flow separation and to supply blowing air upstream. There are lots of other applications which use the MBT besides reducing skin friction. It is possible to control an airplane by adjusting the degree of skin friction on the wings using variable blowing rate. For the objects with a pressure difference between surfaces, such as a wing or a nacelle, a passive MBT can be applied to bleed off air from high pressure surface and to blow out slowly through the low pressure surface. Most foreign objects bounce off the surface because of blowing air. Even if a large foreign object sticks to the surface, it deteriorates only the small area surrounding it and does not spread to a large area such as the case of the Hybrid Laminar Flow Control (HLFC). 


\section{Concluding Remarks}

A proof of concept experiment for the microblowing technique (MBT) has been successfully conducted, and the preliminary results show that 25 to 35-percent skin friction reduction below a flat plate value could be achieved for a wide range of flow conditions. Research indicates that the skin is the most important factor to make the MBT achievable. Three skins have been identified as the MBT skins during this test. The hole aspect ratios of these skins are larger than 4 . The MBT did reduce skin friction by effectively reducing the roughness of the skin with very low blowing flow rate. More experiments are required to determine the optimal MBT skin and to assess the penalty associated with this technique.

\section{Acknowledgment}

The author gratefully acknowledges the encouragement and the effort to obtain financial support provided by $\mathrm{Mr}$. Thomas Biesiadny and $\mathrm{Mr}$. Bobby Sanders. This experiment could not have proceeded in a timely manner without the funding given by Mr. Dennis Huff, especially during the early stage of the development. The author is very grateful to him. The author would like to appreciate the valuable discussions given by Dr. Hsiao C. Kao, Dr. Kamlesh Kapoor, and Dr. Gary Harloff during the development of this concept. The author would like to express sincere thanks to Dr. Greg Tillman of UTRC for reviewing the final draft and providing valuable comments. The author would like to thank Mr. Robert Voisinet of the Naval Surface Weapons Center for providing the balance and $\mathrm{Mr}$. Charles Parente of Northrop Grumman for supplying the test skins. The financial support from the NASA Lewis Research Center Director's Discretionary Fund is greatly appreciated. The following individuals are also acknowledged for their contributions during the execution of the test program: Mr. Tony Herrmann, Miss Gwynn Severt, Mr. Kurt Loos, Mr. Carlos Gomez, Mr. Wayne Stopack, Mr. David Lam, and Miss Wendy Barankiewicz.

\section{References}

1. Bushnell, D.M.; and Hefner, J.N.: Viscous Drag Reduction in Boundary Layers. Progress in Astronautics and Aeronautics, vol. 123, American Institute of Aeronautics and Astronautics, Inc., Washington, D.C., 1990.

2. Special Course on Skin Friction Drag Reduction, AGARD Report No.786, 1992.
3. Jeromin, L.O.F.: The Status of Research in Turbulent Boundary Layers With Fluid Injection. Prog. in Aeronaut. Sci., vol. 10, 1970, pp. 65-189.

4. Voisinet, R.L.P.: Influence of Roughness and Blowing on Compressible Turbulent Boundary Layer Flow-Skin Friction Drag. Final Report. Naval Surface Weapons Report NSWC TR-79-153, 1979.

5. Bushnell, D.M.; Watson, R.D.; and Holly, B.B.: Mach and Reynolds Number Effects on Turbulent Skin Friction Reduction by Injection. J. Space. Rock., vol. 12, Aug. 1975, pp. 506-508.

6. Healzer, J.M.; Moffat R.J.; and Kays, W.M.: The Turbulent Boundary Layer on a Rough, Porous Plate: Experimental Heat Transfer With Uniform Blowing. Stanford University Report No. SW-HMT-18, 1974.

7. Dahm, T.J., et al.: Mass, Momentum, and Heat Transfer Within a Turbulent Boundary Layer With Foreign Gas Mass Transfer at the Surface. Vade Report No. 111, Feb. 1964.

8. Goodwin, B.M.: The Transpired Turbulent Boundary Layer With Zero Pressure Gradient. DSc Thesis, Massachusetts Institute of Technology, May 1961.

9. Kays, W.M.; Moffat, R.J.; and Simpson, R.L.: The Turbulent Boundary Layer on a Porous Plate: Experimental Skin Friction With Variable Injection and Suction. Int. J. Heat Mass Transfer, vol. 12, 1969, pp. 771-789.

10. Dershin, H.; Gallaher, W.H.; and Leonard, C.A.: Direct Measurement of Skin Friction on a Porous Flat Plate With Mass Injection. AIAA Paper 67-194, vol. 5, no. 11, 1967, pp. 1934-1939.

11. Simpson, R.L.: Characteristics of Turbulent Boundary Layers at Low Reynolds Numbers With and Without Transpiration. J. Fluid Mech., vol. 42, 1970, pp. 769-802.

12. Jeromin, L.O.F.: An Experimental Investigation of the Compressible Turbulent Boundary Layer With Air Injection. ARC Reports and Memoranda No. 3526, Aeronautical Research Council, London, England, 1968.

13. Wilkinson, S.P.: Influence of Wall Permeability on Turbulent Boundary-Layer Properties. AIAA Paper 83-0294, 1983.

14. Beltran, L.R.; Del Roso, R.L.; and Del Rosario, R.: Advanced Nozzle and Engine Components Test Facility. NASA TM-103684, 1992.

15. Schlichting, H.: Boundary Layer Theory. McGraw-Hill Book Co., Inc., New York, 1960. 
Table I. - Specifications of Test Plates

\begin{tabular}{|l|c|c|c|c|c|}
\hline Plate name & $\begin{array}{c}\text { Hole cross section shape } \\
\text { (side view) }\end{array}$ & $\begin{array}{c}\text { Hole size, } \\
\text { D, } \\
\text { mm }\end{array}$ & $\begin{array}{c}\text { Thickness of plate, } \\
\text { T, } \\
\text { mm }\end{array}$ & $\begin{array}{c}\text { Porosity, } \\
\text { percent }\end{array}$ & $\begin{array}{c}\text { Aspect ratio, } \\
\text { AR, } \\
\text { T/D }\end{array}$ \\
\hline NASA PN2 & Straight & 0.165 & 1.02 & 23 & 6.2 \\
\hline NASA PN3 & Straight & 0.254 & 1.02 & 23 & 4 \\
\hline GAC 2004 & Conical & 0.381 & 0.787 & 21 & 2.1 \\
\hline GAC 2003 & Conical & 0.152 & 0.305 & 21 & 2 \\
\hline GAC 2005 & Conical & 0.076 & 0.152 & 23 & 2 \\
\hline GAC 2002 & Conical & 0.229 & 0.394 & 31 & 1.7 \\
\hline GAC 1897 & Hourglass & 0.06 & 0.305 & $50 \ddagger$ & 5.1 \\
\hline
\end{tabular}

¥The porosity is 4 percent based on the small neck area.

Table II. - Test Matrix

\begin{tabular}{|l|c|}
\hline Mach numbers & $\begin{array}{c}\text { Blowing flow rate, } \mathrm{kg} / \mathrm{m} 2 / \mathrm{sec} \\
\text { (percent of maximum blowing rate) }\end{array}$ \\
\hline \multirow{4}{*}{$0.3,0.4,0.5,0.6$, and 0.7} & 0 \\
\cline { 2 - 3 } & $0.019(9.3$ percent) \\
\cline { 2 - 3 } & $0.054(26.2$ percent $)$ \\
\cline { 2 - 3 } & $0.066(32.1$ percent $)$ \\
\cline { 2 - 3 } & $0.1025(50$ percent $)$ \\
\cline { 2 - 3 } & $0.146(71.4$ percent $)$ \\
\cline { 2 - 3 } & $0.176(85.7$ percent $)$ \\
\hline & $0.205(100$ percent $)$ \\
\hline
\end{tabular}

Maximum blowing rate was limited by the size of the flowmeter.

Table III. - Comparison Between Direct

Measurement and Calculated $C_{f}$

\begin{tabular}{|c|c|c|c|}
\hline \multirow{2}{*}{$\begin{array}{c}\text { Blowing rate, } \\
\mathrm{kg} / \mathrm{m} 2 / \mathrm{sec}\end{array}$} & \multicolumn{2}{|c|}{ Total skin friction coefficient, $\mathrm{C}_{\mathrm{f}}$} & \multirow{2}{*}{$\begin{array}{c}\text { Percent } \\
\text { difference }\end{array}$} \\
\cline { 2 - 3 } & Measured & Calculated & \\
\hline 0 & 0.00441 & 0.00441 & 0 \\
\hline 0.054 & 0.0039 & 0.00397 & 2 \\
\hline 0.066 & 0.00379 & 0.00378 & 0 \\
\hline 0.1025 & 0.00351 & 0.00348 & -1 \\
\hline 0.146 & 0.00323 & 0.00321 & -1 \\
\hline 0.176 & 0.00307 & 0.00303 & -1 \\
\hline 0.205 & 0.00292 & 0.003 & 2 \\
\hline
\end{tabular}




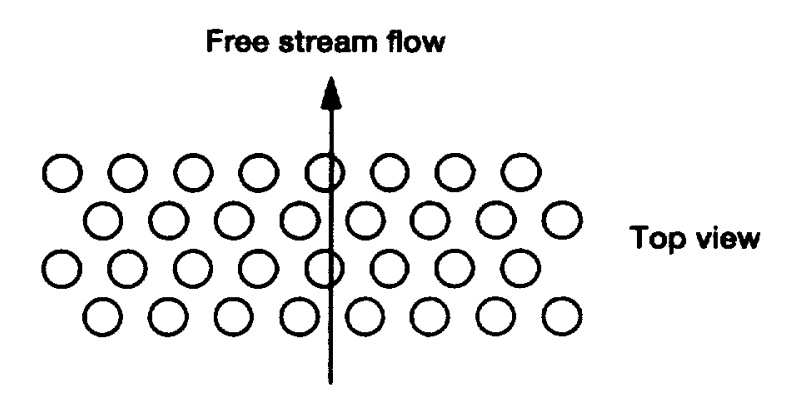

\section{Outer layer}

(Controls vertical flow, a plate with high porosity laser drilled vertical holes)

\section{Inner layer}

(Controls low flow rate, and evenly distributed flow, low permeable porous plate)

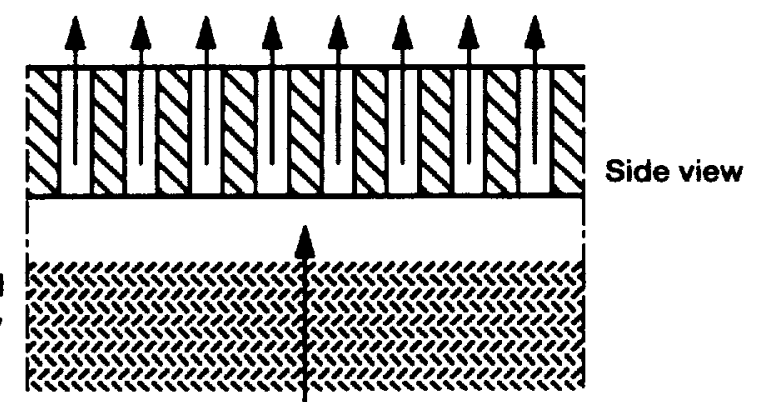

Blowing air supply

Fig. 1.-Micro-Blowing Technique (MBT) skin.

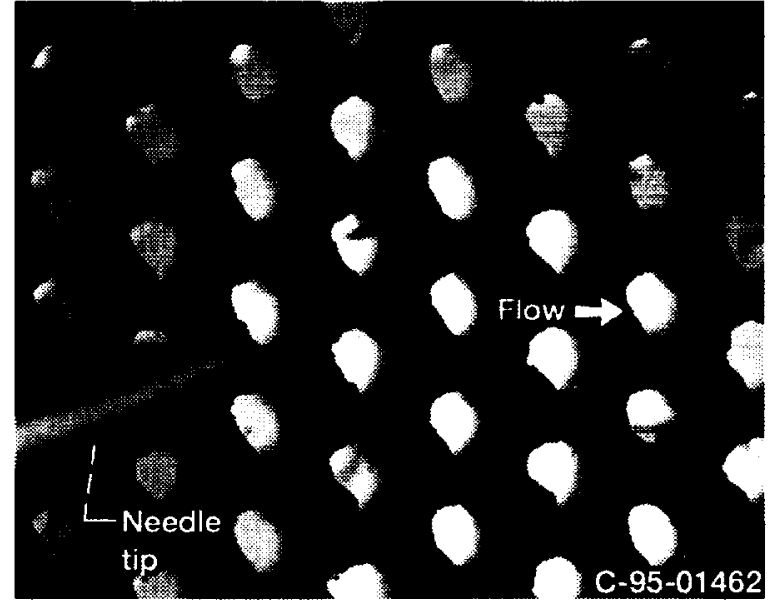

Fig. 2.-Shape of laser drilled holes.

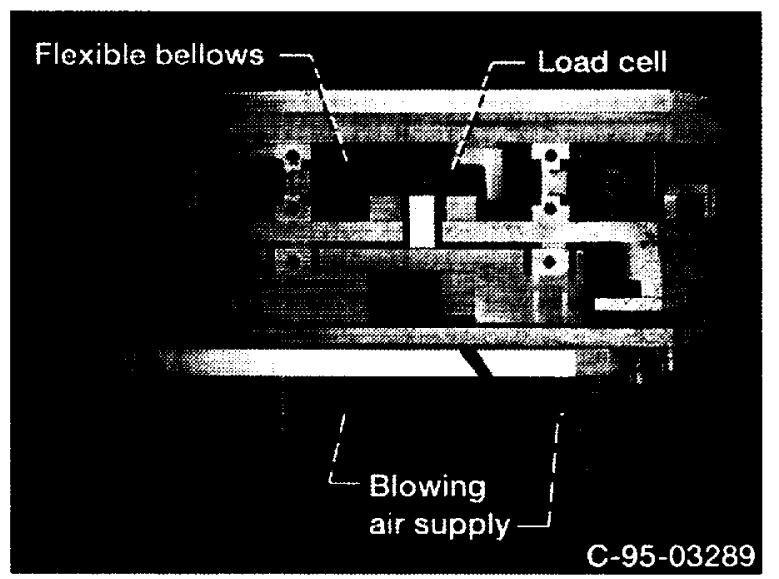

Fig. 3.-Balance used to measure skin friction. 


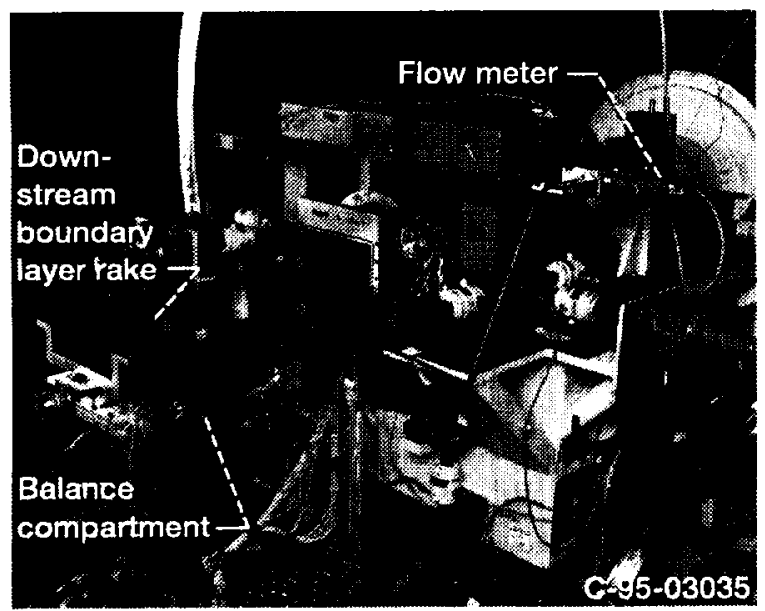

Fig. 4.-Experimental setup.

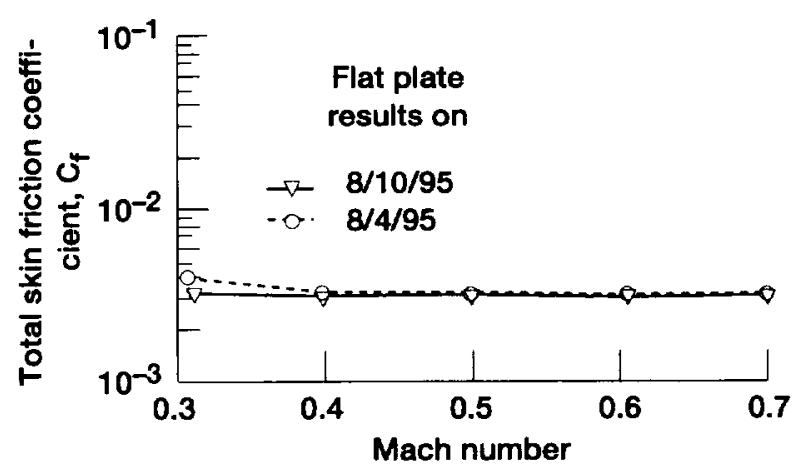

Fig. 5.-Repeatability of test facility.

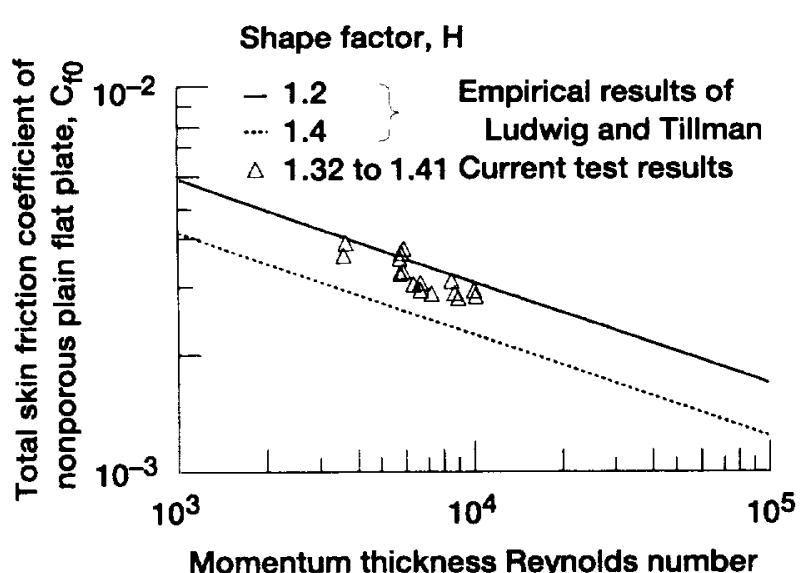

Fig. 6.-Skin friction coefficient of flat plate.

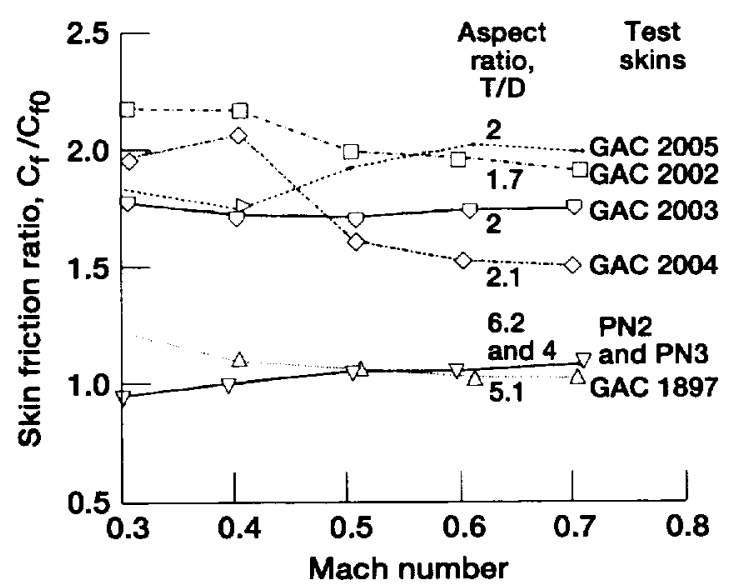

Fig. 7.-Unblown skin friction ratios.

\section{Percent of maximum} blowing rate

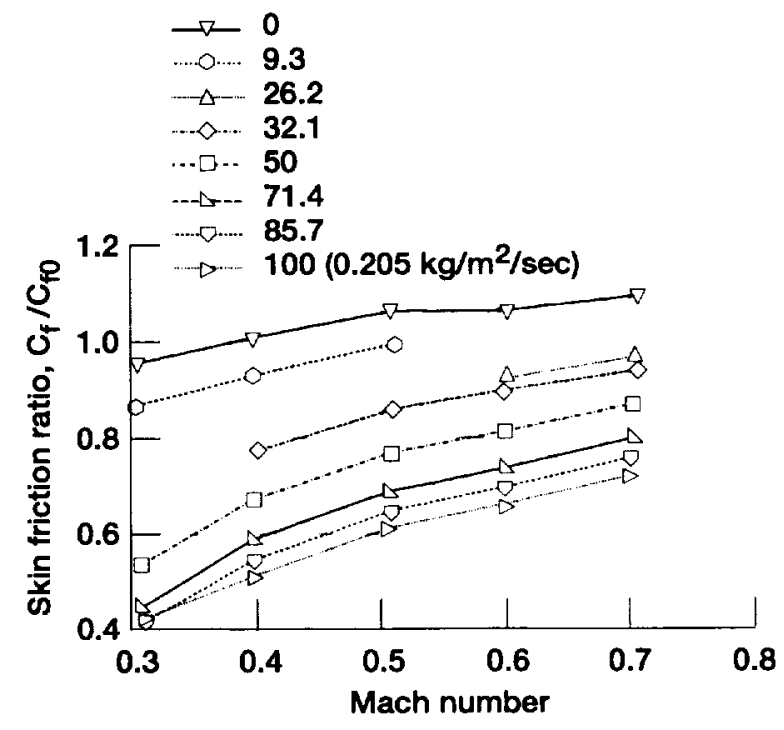

Fig. 8.-Skin friction ratio of NASA PN2 at exhaust pressure of $0.24 \mathrm{~atm}$. 


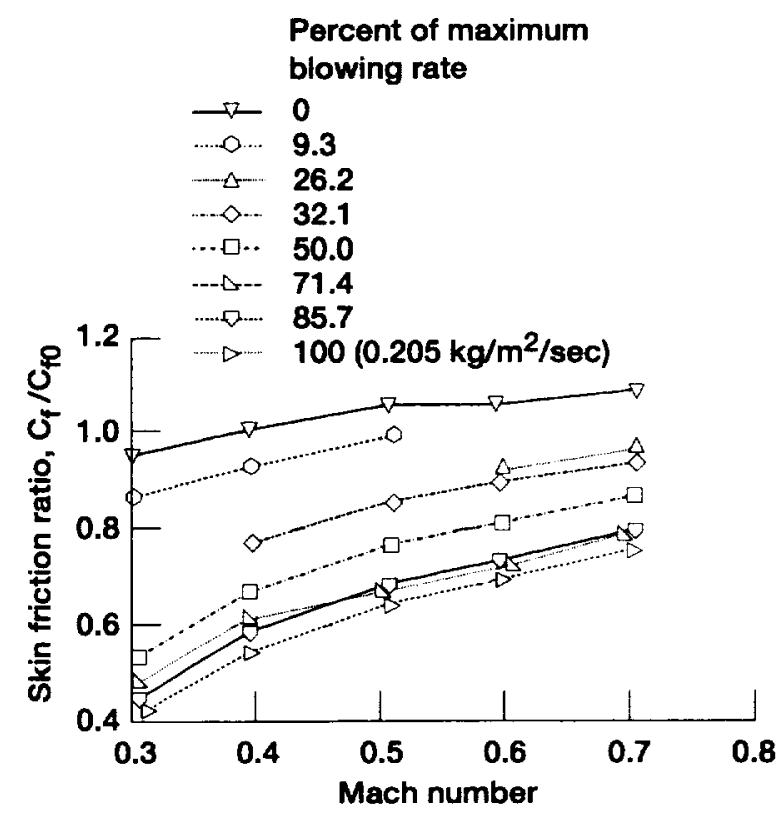

Fig. 9.-Skin friction ratio of NASA PN3 at exhaust pressure of $0.24 \mathrm{~atm}$.

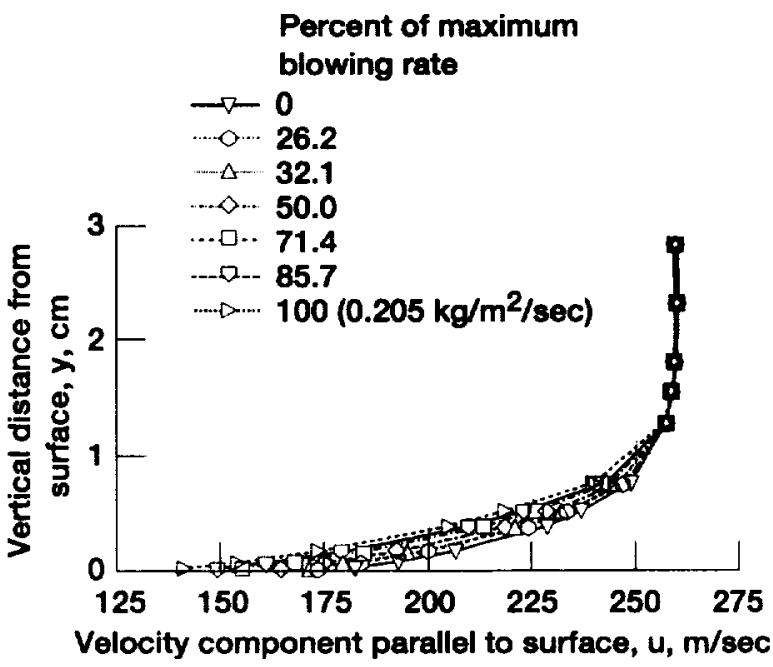

Fig. 11. - Velocity profile at downstream rake; NASA PN2; Mach number $=0.7$.

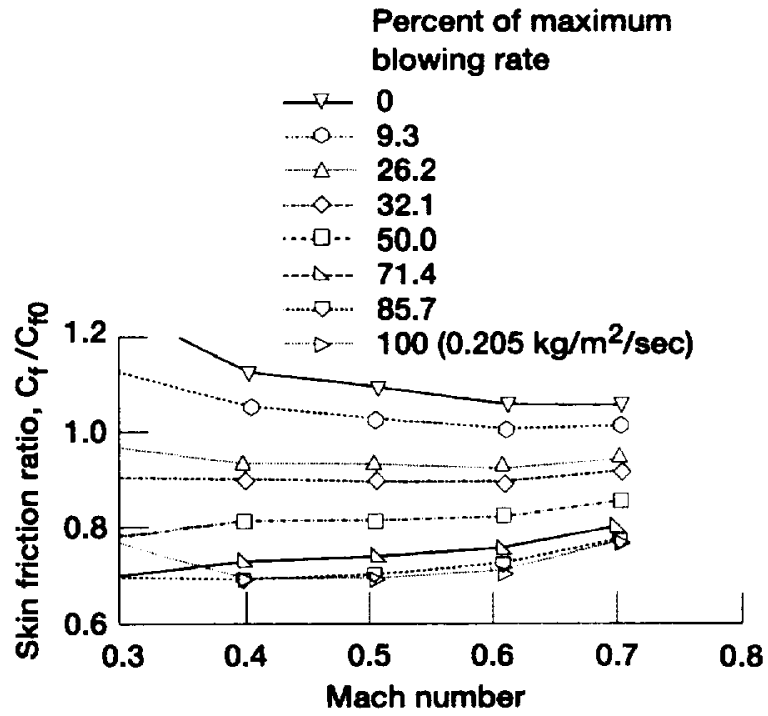

Fig.10.-Skin friction ratio of GAC 1897 at exhaust pressure of $0.24 \mathrm{~atm}$.

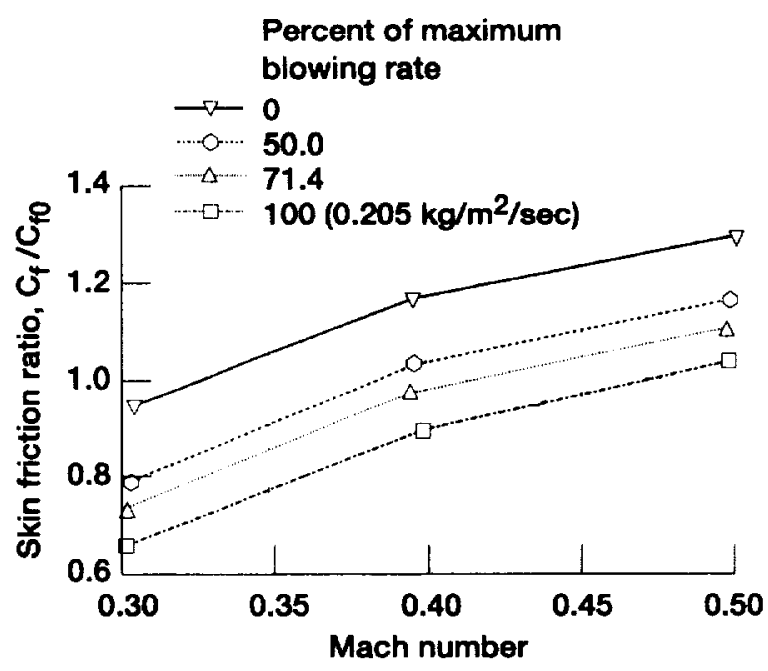

Fig. 12. - Skin friction ratio of NASA PN2 at exhaust pressure of $0.85 \mathrm{~atm}$. 


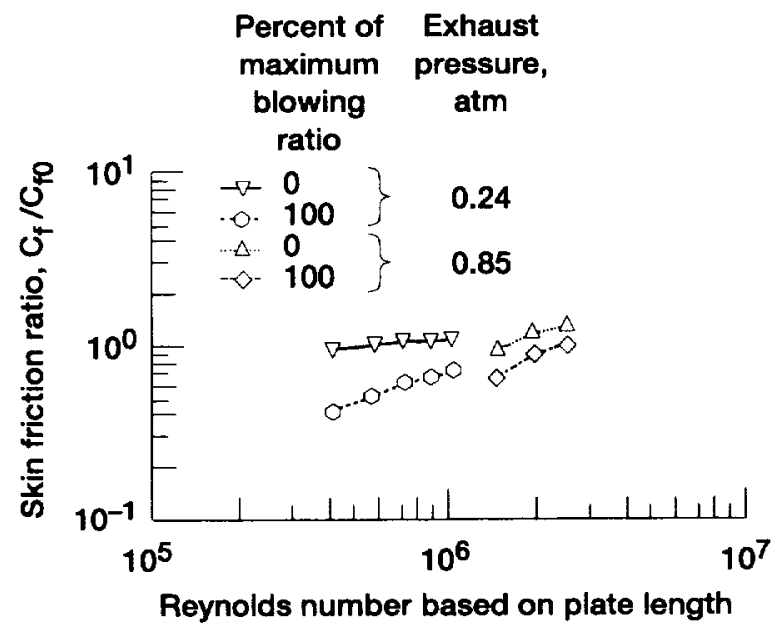

Fig. 13.-Effect of Reynolds number on total skin friction reduction for PN2.

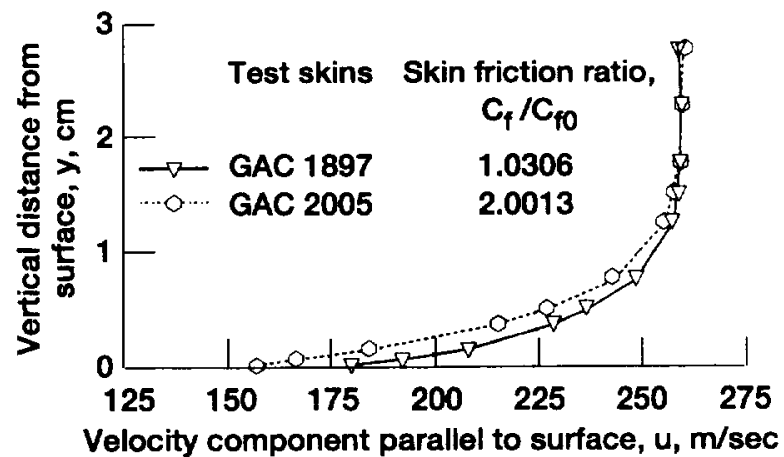

Fig. 14.-Velocity profiles of two skins; Mach number $=0.7$; no blowing. 
Public reporting burden for this collection of information is estimated to average 1 hour per response, including the time for reviewing instructions, searching existing data sources, gathering and maintaining the data needed, and completing and reviewing the collection of information. Send comments regarding this burden estimate or any other aspect of this collection of information, including suggestions for reducing this burden, to Washington Headquarters Services, Directorate for Information Operations and Reports, 1215 Jefferson Davis Highway, Suite 1204, Artington, VA 22202-4302, and to the Office of Management and Budget, Papenwork Reduction Project (0704-0188), Washington, DC 20503.

\begin{tabular}{|l|c|c|}
\hline 1. AGENCY USE ONLY (Leave blank) & $\begin{array}{c}\text { 2. REPORT DATE } \\
\text { October } 1996\end{array}$ & $\begin{array}{c}\text { 3. AEPORT TYPE AND DATES COVERED } \\
\text { Technical Memorandum }\end{array}$ \\
\hline
\end{tabular}

4. TITLE AND SUBTITLE

5. FUNDING NUMBERS

A Proof of Concept Experiment for Reducing Skin Friction By Using a Micro-Blowing Technique

6. AUTHOR(S)

WU-274-00-00

Danny P. Hwang

7. PERFORMING ORGANIZATION NAME(S) AND ADDRESS(ES)

National Aeronautics and Space Administration

Lewis Research Center

Cleveland, Ohio 44135-3191

8. Performing organization REPORT NUMBER

E-10412

9. SPONSORINGMONTORING AGENCY NAME(S) AND ADDRESS(ES)

10. SPONSORINGMONITORING AGENCY REPORT NUMBER

National Aeronautics and Space Administration

Washington, D.C. 20546-0001

NASA TM-107315

AIAA-97-0546

\section{SUPPLEMENTARY NOTES}

Prepared for the 35th Aerospace Sciences Meeting and Exhibit sponsored by the American Institute of Aeronautics and Astronautics, Reno, Nevada, January 6-9, 1997. Responsible person, Danny P. Hwang, organization code 5850, (216) 433-2187.

12a. DISTRIBUTION/AVAILABILITY STATEMENT 12b. DISTRIBUTION CODE

Unclassified - Unlimited

Subject Category 34

This publication is available from the NASA Center for AeroSpace Information, (301) 621-0390.

13. ABSTRACT (Meximum 200 words)

A proof of concept experiment for reducing skin friction has been conducted in the Advanced Nozzle and Engine Components Test Facility at the NASA Lewis Research Center. In this unique concept, called the micro-blowing technique (MBT), an extremely small amount of air was blown vertically through very small holes to reduce the surface roughness and to control the gradient of the flow velocity profile on the surface thereby reducing skin friction. Research revealed that the skin was the most important factor to make this concept achievable. The proposed skin consisted of two layers. The inner layer was a low permeable porous skin for distributing the blowing air evenly while the outer layer with small holes controlled the vertical or nearly vertical blowing air. Preliminary experimental results showed that the MBT has the potential of a very large reduction in skin friction below the skin friction of a nonporous plain flat plate. Of the skins tested, three have been identified as the MBT skins. They provided very low unblown skin friction such that a large skin friction reduction, below a flat plate value, was achieved with very small amounts of blowing air. The reduction in skin friction of 55 percent was achieved at the Mach number of 0.3 for the exhaust pressure of $0.85 \mathrm{~atm}$, and 60 percent reduction was obtained for the exhaust pressure of $0.24 \mathrm{~atm}$ (corresponding to 10700 -m altitude) at the same Mach number. A significant reduction in skin friction of over 25 percent was achieved for the exhaust pressure of 0.24 atm at the Mach number of 0.7 . This implied that the MBT could be applied to a wide range of flight conditions. It is also believed that additional 10 percent reduction could be obtained by eliminating the gap between the inner layer and the outer layer. The aspect ratio of the vertical small holes for the outer layer of the MBT skin should be larger than 4 based on the preliminary conclusion from this test. Many experiments are needed to find out the optimal MBT skin. The penalty associated with the MBT needs to be assessed. However, preliminary results indicated that the MBT could provide a 25 to 35 percent reduction for real-world application. The concept can be applied to not only an airplane, but also a missile, a submarine (microblow water instead of air), and an ocean liner.

\section{SUBJECT TERMS}

Micro-blowing; Skin friction reduction; Porous plate

15. NUMBER OF PAGES

\begin{tabular}{|c|c|c|}
\hline $\begin{array}{c}\text { 17. SECURTY CLASSIFICATION } \\
\text { OF REPORT } \\
\text { Unclassified }\end{array}$ & $\begin{array}{c}\text { 18. SECURITY CLASSIFICATION } \\
\text { OF THIS PAGE } \\
\text { Unclassified }\end{array}$ & $\begin{array}{c}\text { 19. SECURIT CLASSIFICATION } \\
\text { OF ABSTRACT } \\
\text { Unclassified }\end{array}$
\end{tabular}

